\title{
PREPARING FOR LIFE OR PROTECTING AGAINST DEATH? OBSERVATIONS PERTAINING TO THE LATE MEDIEVAL MINIATURE AXES BASED ON EXAMPLES FROM THE BORDERLAND OF GREATER POLAND, SILESIA AND BRANDENBURG
}

\author{
ARKADIUSZ MICHALAK
}

\begin{abstract}
There are known over twenty late-medieval, iron axes from Poland with significantly reduced sizes. Three of them were excavated in the borderland of Silesia, Greater Poland and Brandenburg from stronghold-castle and urban archaeological contexts. In the scholarship, these artefacts were considered amulets, toys, weapons, badges and tools. Author concludes that smaller specimens, could have been used as apotropaic amulets or objects related to the cult of St. Wolfgang, while larger axes, with hardened blades, were most likely specialized carpentry tools, adopted perhaps also in self-defense, if necessary.
\end{abstract}

Key words: miniature axe-Polish lands-Medieval-childhood-toy-emblem-St. Wolfgang-carpenter tool.

Př́prava na život nebo ochrana před smrtí? Poznámky k pozdně středověkým miniaturním sekerkám z pomezí Velkopolska, Slezska a Braniborska

\begin{abstract}
Abstrakt: Z územi Polska je známo více než dvacet pozdně středověkých železných seker s výrazně zmenšenými rozměry. Tři z nich byly objeveny na pomezi Slezska, Velkopolska a Braniborska, přičemž pocházejí z fortifikovaných sidel a městských nálezových kontexti̊. Vodborné literatuře byly tyto artefakty považovány za amulety, hračky, zbraně, odznaky či nástroje. Autor docházi k závěru, že menši exempláře mohly být použivány jako apotropaické amulety nebo předměty souvisejicí s kultem svatého Wolfganga, zatímco větši sekery s kaleným ostřim byly nejspíše specializovaným tesařským nár̆adím, v připadě potřeby snad uživaným i jako príležitostná zbraň.
\end{abstract}

Klićová slova: miniaturní sekerky - Polské země - středověk - dětství - hračka - amulet - sv. Wolfgang tesařský nástroj.

Gathering materials for a work devoted to late-medieval arms and armour from the borderland of Silesia, Greater Poland, Brandenburg and Lusatia (included within today's borders of the Lubuskie Voivodeship, on the western frontier of Poland; Michalak 2019; see Łaszkiewicz-Michalak 2007, 117), resulted in finding 3 miniature axes resembling the form of standard late-medieval specimens. Some researchers consider standard size late medieval axes primarily as weapons, while they were mainly tools with a variety of other cultural functions (Goodman 1964, 29; Głosek 1996; 2004, 240, Fig. I:5; Michalak 2019, 259). The relatively small size of these artefacts prompted me to conclude that they did not belong to the category of arms. ${ }^{1}$ However, these finds, resulted in a search for the purpose of this type of axes, which had previously been interpreted in various ways (Fig. 1). I will discuss that below in detail.

The analyzed axes have a length not exceeding $10 \mathrm{~cm}$. Two of them were discovered in Międzyrzecz, in the historic Greater Poland, on the municipal parcel and the area of strongholdcastle. Due to their form, they can be classified as type IV C according to A. Nadolski $(1954,44)$, who believed that axes of this form were used already in the 11th century. M. Głosek $(1996,34)$ revived such an early dating, on the basis of the finds from Raciąż in Pomerania (Świątkiewicz 2010, 23-25), and shifting it to the end of the first half of the 13th and the beginning of the 14th centuries. The artefact matching the chronology of these findings was obtained during the excavations of the Międzyrzecz stronghold (Fig. 2:1), in the layers dating from 1269 to the 80s (90s) of the 13th century (Kurnatowski 1961, Fig. 44:5; Banach 2016, 348, Fig. 211:5). The second specimen

1 Impacts of such a low weight axe head would only cause injury if directed against an unarmored opponent. It seems that axes of this size were not used in combat conditions. 


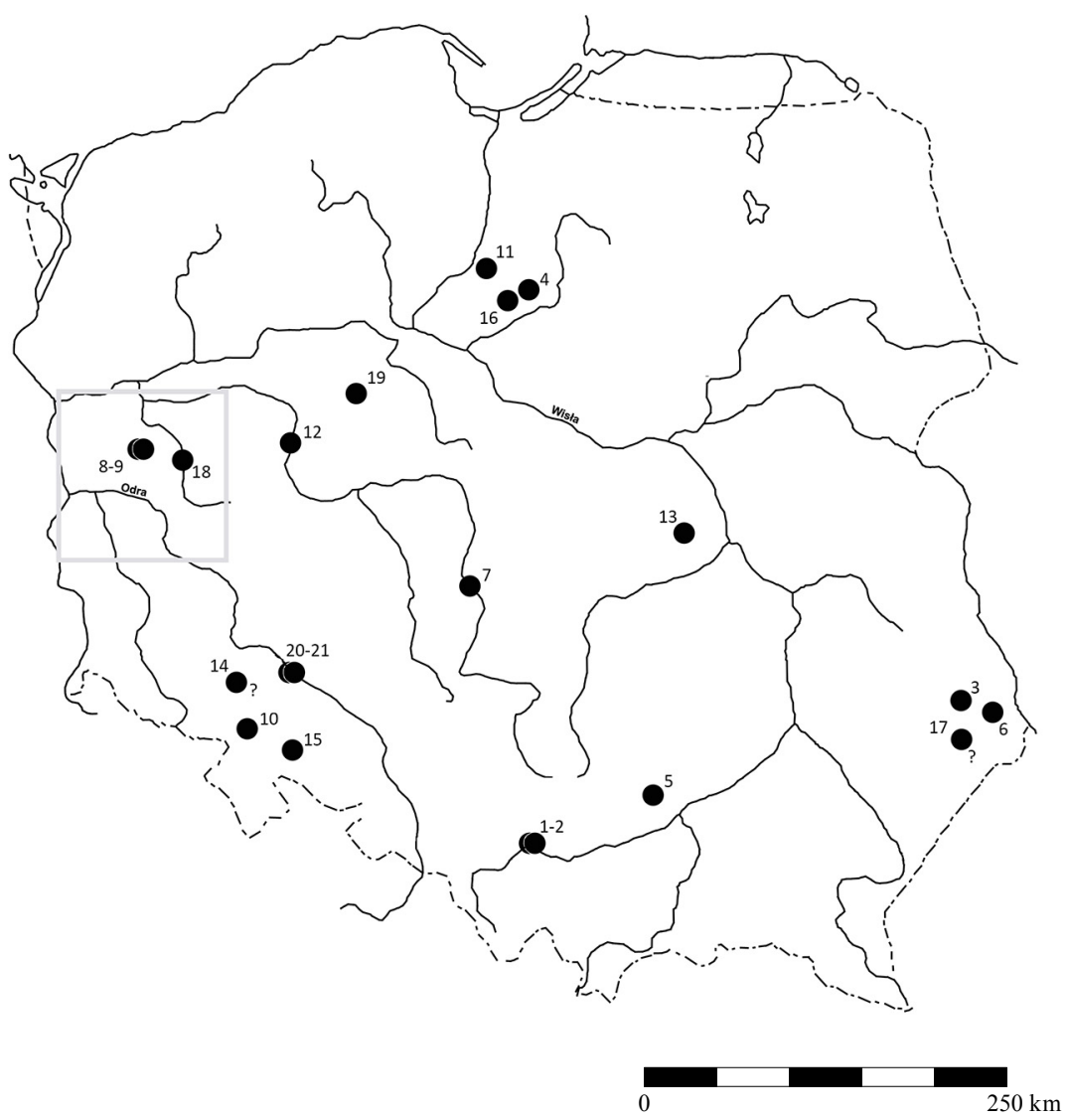

Fig. 1. Distribution of iron, miniature, late medieval axes from the territory of Poland. 1-2 -Babice (Lipowiec Castle), Chrzanów County; 3 - Borowica, Krasny Staw County; 4 - Brodnica, Brodnica County; 5 - Dziesławice, Oleśnica County; 6 - Horodysko, Chełm County; 7 - Kalisz, Kalisz County; 8-9 - Międzyrzecz, Międzyrzecz County; 10 - Pieszyce, Dzierżoniów County; 11 - Plemięta, Grudziądz County; 12 - Poznań, Poznań County; 13 - Radom, Radom County; 14 - Silesia, location unknown; 15 - Skoroszowice, Strzelin County; 16 - Sloszewy, Brodnica County; 17 - Solska Forest, location unknown; 18 Trzciel, Międzyrzecz County; 19 - Wolskie Lake, Żnin County; 20-21 - Wroclaw, Wroclaw County. Drawing A. Michalak.

Obr. 1. Rozšíření pozdně středověkých miniaturních železných sekerek z území Polska: 1-2 - Babice (hrad Lipowiec), okres Chrzanów; 3 - Borowica, okres Krasny Staw; 4 - Brodnica, okres Brodnica; 5 - Dziesławice, okres Oleśnica; 6 - Horodysko, okres Chełm; 7 - Kalisz, okres Kalisz; 8-9 - Międzyrzecz, okres Międzyrzecz; 10 - Pieszyce, okres Dzierżoniów; 11 - Plemięta, okres Grudziądz; 12 - Poznaň, okres Poznaň; 13 - Radom, okres Radom; 14 - Slezsko, neznámá lokalita; 15 - Skoroszowice, okres Strzelin; 16 - Sloszewy, okres Brodnica; 17 - les Solska, neznámá lokalita; 18 - Trzciel, okres Międzyrzecz; 19 - Wolskie jezero, okres Żnin; 20-21 - Wroclaw, okres Wroclaw. Kresba A. Michalak.

from Międzyrzecz (Fig. 2:2) was discovered on a municipal parcel (Łaszkiewicz-Michalak 2007, 117, Fig. 5:2), where primarily existed the layers characteristic for the 15th century and modern times (Szczurek 2005). It seems that despite some discrepancy between typology and stratigraphy, it should also be dated this way. The possibility of a longer existence of this form should be assumed by find of this type of axe from the Early Medieval context at Gniezno (Lukasiewicz 1938, 43, Pl. XLIV:2), as well as by the long-term use of these artefacts (functionality; see below). The third miniature specimen, slightly larger in size, found during the excavations of the motte type stronghold in Trzciel, has the shape characteristic of type IX according to M. Głosek (1996; Fig. 2:3). The stratigraphy of the site allows to date this axe only generally to the period of stronghold existence, between 13th and 16th centuries (Kołodziejski 1965; 1967). 

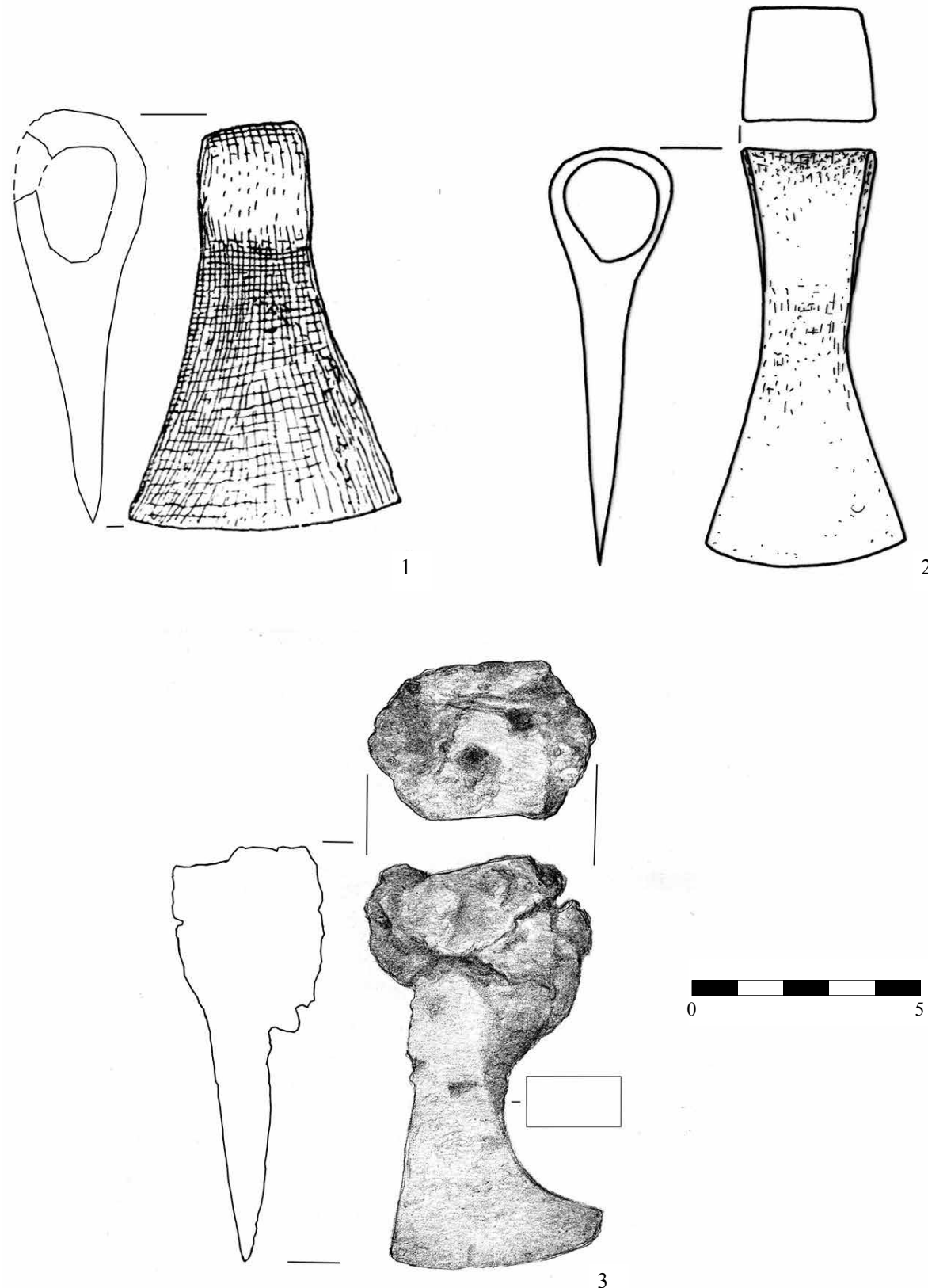

0 $5 \mathrm{~cm}$

Fig. 2. Late medieval, iron miniature axes from the borderland of Silesia, Brandenburg and Poland: 1-2 - Międzyrzecz; 3 - Trzciel. 1 after Kurnatowski 1961; 2 after Laszkiewicz-Michalak 2007; 3 drawn by A. Sabak-Stachowiak.

Obr. 2. Pozdně stř̌edověké miniaturní železné sekerky z pomezí Slezska, Braniborska a Polska. 1-2 - Międzyrzecz; 3 - Trzciel. 1 podle Kurnatowski 1961; 2 podle Laszkiewicz-Michalak 2007; 3 kresba A. Sabak-Stachowiak. 
The standard sizes of the Type IV C specimens have an average overall length of $14.0-29.0 \mathrm{~cm}$, with blade width of $8.6-16.5 \mathrm{~cm}$, and diameter of shaft hole of $3.6-7 \mathrm{~cm}$. Specimens classified as the Type IX are of 15-25 cm long. The artefacts in question definitely differ from the specimens with the average dimensions. From Poland there are known over 20 similar late-medieval axes with significantly reduced sizes (Fig. 1). They represent different types of M. Głosek's classification: VIIa (Kalisz), VIIIa (Wolskie Lake), IX (Babice, Poznań, Radom), IXa (Babice, Horodysko), Xa (Brodnica), XIII (Słoszewy); most of the artefacts have the shape characteristic for the Type VIII (Borowica, Dziesławice, Pieszyce, Plemięta, Skoroszowice, Wrocław x 2, Silesia, Solska Forest; Dąbrowska 1965; 67, 202; Jasiński 1982, 22, Pl. X; Kola 1985, 151, Pl. XX:3; Głosek 1996, 53, 86-87, Pl. XV:B-C; XVIII:C, XXXV:E; 1997, 160-161, Fig. 2, 4; Boguszewicz 2000, 73, Fig. 8:20; Sikorski 2000, 110; Ławrynowicz-Strzyż 2001, 262, Fig. 2:6; Grążawski 2003, Fig. 12:6; Kotowicz 2004, Photo 2; 2013; Kucypera-Pranke-Wadyl 2011, Pl. XXIV-XXV; Fig. 3-4). Vast majority of these axes come from stronghold-castle and urban archaeological contexts, which, however, do not provide unambiguous grounds for determining their function. Some of these specimens have archaeological dating based on independent determinants that span the period from the 13th to the 15 th centuries. ${ }^{2}$ This dating basically does not differ from the chronology of particular types of standard sized specimens established by M. Głosek (1996). Many late-medieval miniature axes are also known from Europe, where they occur not only in the Middle Ages, but are also found in Early Modern strata (Möbes-Timpel 1987, Abb. 36:19; Steuer 1993, Abb. 8:3; Popovici 2002, Fig. 6:2; Irásné Melis 2004, 40:13 kep.; Terei-Horváth 2007, 15:3 kep.; Савицький-Охріменко 2007. P. 135, Fig. 6:4). In the literature, when discussing the published finds, these types of artefacts were considered amulets, toys, weapons, badges and tools. ${ }^{3}$

Let us consider for a moment the interpretation of the discussed axes as items related to the realm of childhood. The link between the objects in question and toys was previously suggested by A. Boguszewicz $(2000,73)$ and Cz. Sikorski $(2000,110)$. During the fieldworks at various archaeological sites dating to the Middle Ages, objects of reduced size and shapes, imitating weapons or tools, are often found (wooden or bone swords, daggers, spears and arrows; Hoffmann 1996, 154-155, cat. 115-117, 119, 121-123, Abb. 91:2-7, 9; Willemsen 1997, 406; Blaževičius 2008, 80-81; Kotowicz 2008; Żołądź-Strzelczyk 2013). These items were to prepare children for life in the world of adults (Świderska 2001, 105; see Delimata 2004). However, let's note that most of these items were made of organic materials, what made them easier to make, did not expose the creator to high costs, and limited injuries caused during the games; additionally, these are individual copies (Kunicka-Okuliczowa 1959, 129). Obviously, the Late Medieval metal military toys are known, but they were made mainly of non-ferrous metals (Bracker 1989; Egan 1997, 417-418; Kotowicz-Muzyczuk 2008, 134). Certainly, children of the upper strata of society had toys that exquisitely reflected the features of real objects (c.f. Sensfelder 2008); however, this seems unlikely in the case of these types of axes. That could suggest these kinds of artefacts should not be interpreted as toys, although, on the other hand, it cannot be ruled out that they were made for children. The products of material culture may certify or identify the stages and behaviors that are conditional for the young individual's full acceptance to the group. Such objects would have helped the child to become aware of his/her own identity, helped to accumulate

2 E.g. Horodysko - 13th-14th centuries, Plemięta - 13th-14th centuries, Kalisz - 13th century, Brodnica - 1347-1785, Radom - mid-13th mid 14th centuries, Babice (Lipowiec Castle) - 14th century and 14th-15th centuries, Pieszyce -13 th -14 th centuries, Słoszewy - 14th - first quarter of the 15th centuries, Poznań - 1500-1700, Wrocław - second half of the 13th - second half of the 19th centuries. Specimens from unspecified place in Silesia, Borowica, Dziesławice, Skoroszowice, Solska Forest and Wolskie Lake are loose finds, and can be only dated by means of classification analysis.

3 I would also not exclude the interpretation as votive gift during colonisation that is sometimes attributed to the specimens from the Early Medieval period (Vlasatý 2020). This idea is based on the assumption that the miniature axes symbolically represent the standard size specimens. In the Early Middle Ages symbolic significance of axe-tool during the process of cultivation of land was strongly emphasized. The custom of burying the axe in the ground by the settlers taking the new land, as a symbol for bringing there an order, was most likely based on this idea (Starý-Kozák 2010, 44-45). Parallels from the late Neolithic era indicate that this habit could have had prehistoric tradition. Axes then had been buried in the ground to probably define estate boundaries with the purpose of protecting it from disruption (Rønne 2008). One need to have in mind that many of the traditions with pagan roots were still cultivated deep into the medieval period, even though the church officially forbade them (Michalak 2015, 300). 

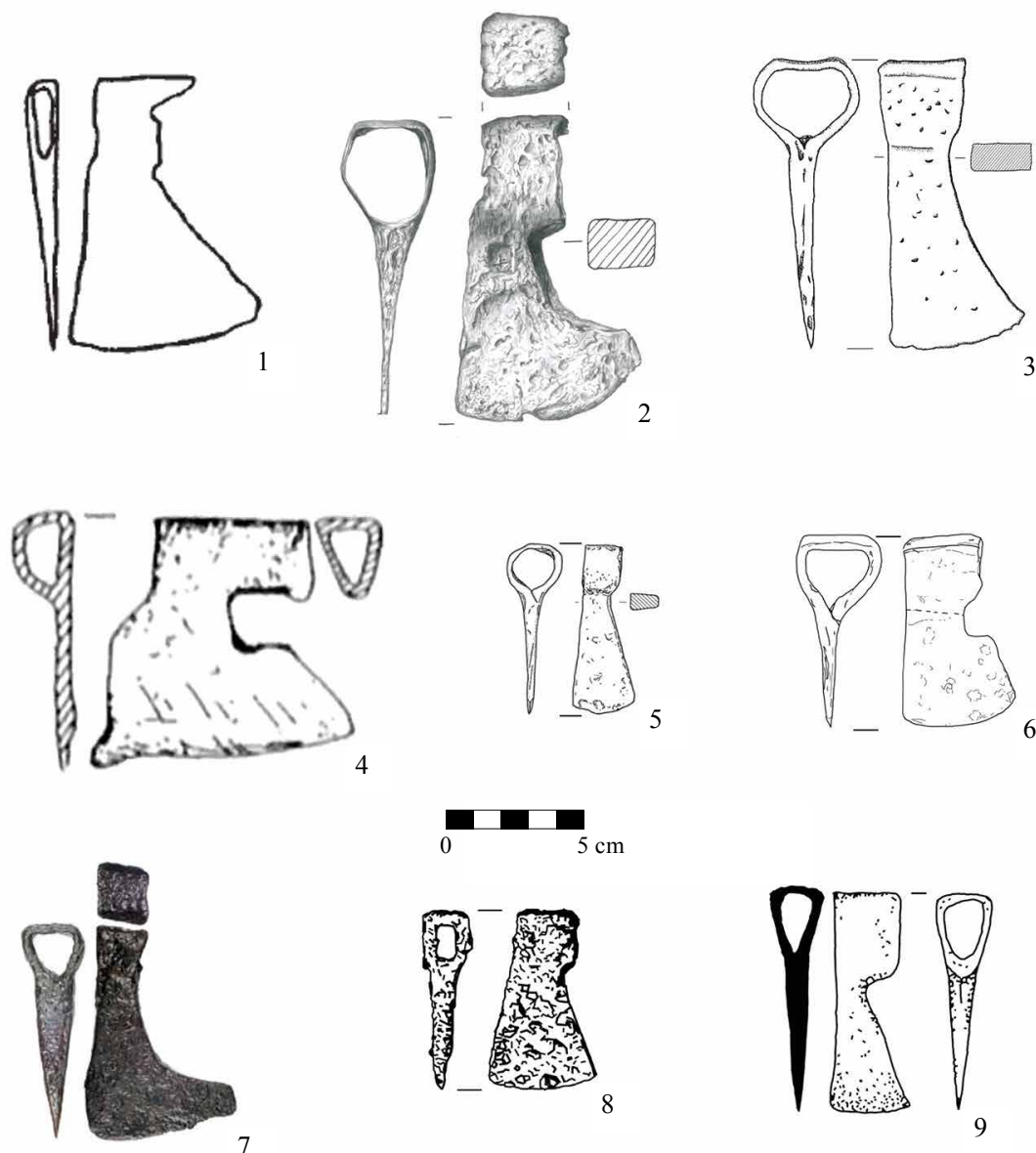

Fig. 3. Iron, late medieval miniature axes from the territory of Poland. 1-2 - Babice (Lipowiec Castle); 3 - Borowica; 4 Brodnica; 5 -Dzieslawice; 6 - Horodysko; 7 - Kalisz; 8 - Pieszyce; 9 - Plemięta. 1 after Glosek 1996; 2 drawn by A. Michalak, J. Sójkowska-Socha; 3, 5-6 drawn by P. Kotowicz; 4 after Grążawski 2003; 7 after Kędzierski-Wyczólkowski 2014; 8 after Boguszewicz 2000; 9 after Kola 1985.

Obr. 3. Pozdně stř̌edověké miniaturní železné sekerky z území Polska. 1-2 - Babice (hrad Lipowiec); 3 - Borowica; 4 - Brodnica; 5 - Dzieslawice; 6 - Horodysko; 7 - Kalisz; 8 - Pieszyce; 9 - Plemięta. 1 podle Glosek 1996; 2 kresba A. Michalak, J. Sójkowska-Socha; 3, 5-6 kresba P. Kotowicz; 4 podle Grążawski 2003; 7 podle Kędzierski-Wyczólkowski 2014; 8 podle Boguszewicz 2000; 9 podle Kola 1985.

knowledge that would allow the child to recognize and take up roles or functions in accordance with social expectations (Kurasiński 2010, 226-227). Although they could be objects similar in nature to modern toys, their symbolic meaning was much broader. Among many peoples, it was customary to give children certain items on the occasion of particular ceremonies (e.g., birth, naming, baptism). These gifts often determined the future profession of a new member of the community (Biegeleisen 1927, 174-176).

The interpretation of these artefacts as signs of belonging to a specific social group or subordination should be rather excluded. Miniature metal axe heads are known in Europe from the Roman period through the early and late Middle Ages (Kokowski 1997; Beilke-Vogt 1998). Some scholars consider early medieval specimens a sign of belonging to the warrior class, given 

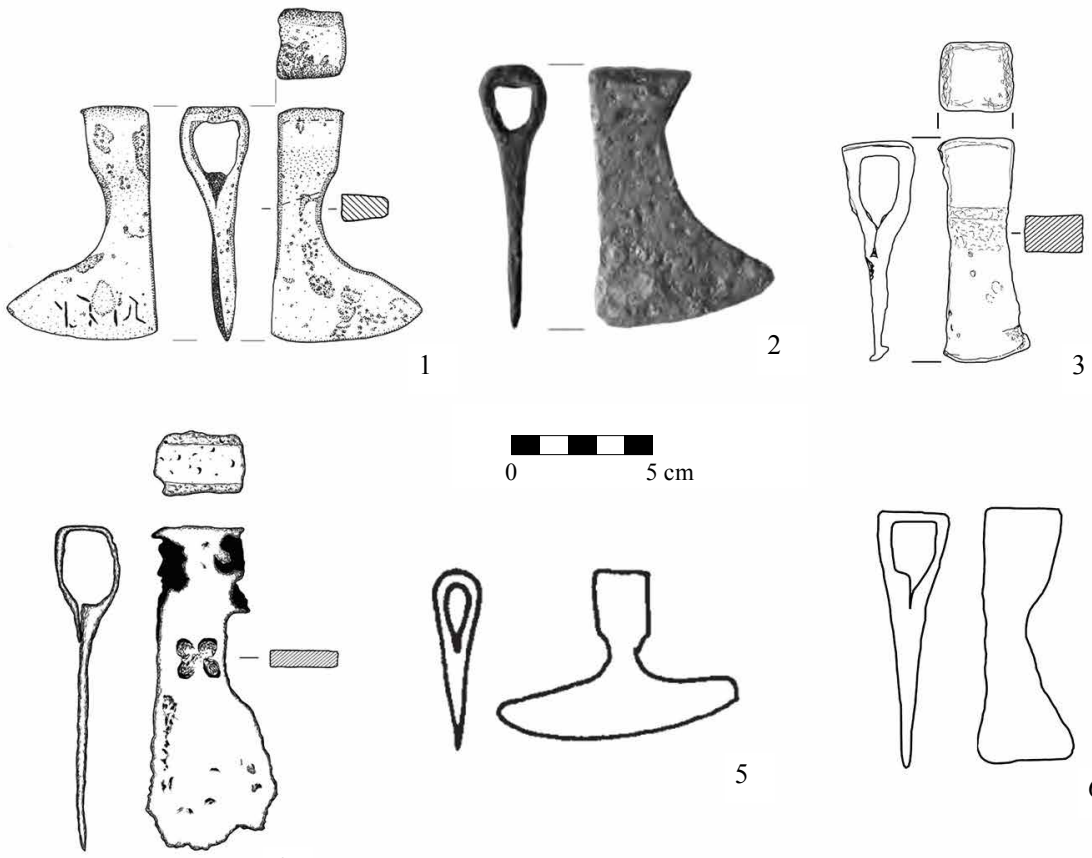

4
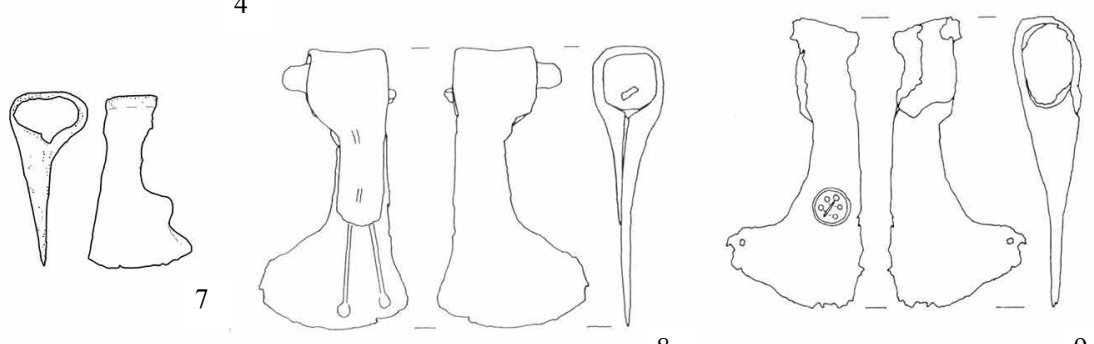

8

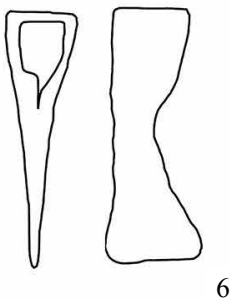

6

Fig. 4. Iron, late medieval miniature axes from the territory of Poland. 1 - Poznań; 2 - Radom; 3 -Silesia; 4 -Skoroszowice; 5 - Sloszewy; 6 - Solska Forest; 7 - Wolskie Lake; 8-9 Wroclaw. 1 after Kotowicz 2012; 2 after Auch-Trzeciecki-Stańczuk 2020; 3-4 drawn by A. Michalak; 5 after Glosek 1996; 6 after Lawrynowicz-Strzyż 2003; 7 after Jasiński 1982; 8-9 after Glosek 1997.

Obr. 4. Pozdně stř̌edověké miniaturní železné sekerky z území Polska: 1 - Poznań; 2 - Radom; 3 - Slezsko; 4 - Skoroszowice; 5 - Sloszewy; 6 - les Solska; 7 - Wolskie jezero; 8-9 Wroclaw. 1 podle Kotowicz 2012; 2 podle Auch-Trzeciecki-Stańczuk 2020; 3-4 kresba A. Michalak; 5 podle Głosek 1996; 6 podle Lawrynowicz-Strzyż 2003; 7 podle Jasiński 1982; 8-9 podle Glosek 1997.

to the sons of members of Ruthenian druzhina at the time of the first haircut. Such axes played the role of an apotropaic emblem within the dangerous life of a warrior, at the same time it symbolized attachment to the old pagan faith in the era of progressive Christianization. Also, upon the boy's unexpected death, it was placed in his grave (Макаров 1992, 4851). Many scholars, using (often groundlessly) simple analogies regarding miniatures of Roman period or Early Medieval axes, also attribute their functions to items with late medieval forms (Савицький-Охріменко 2007, 135, Fig. 6:4). Note that late medieval badges in the form of an axe were made primarily of non-ferrous metals (tin and copper) and were much smaller in size (up to $5 \mathrm{~cm}$; Spencer 1998, 302-307; Kotowicz-Muzyczuk 2008, 134-135; Sawicki 2014, Figs. 10-11; Paner 2016, 386-403). 
Most studies on miniature axes from the Early and Late Middle Ages associate their occurrence with the cult of the gods Thor or Perun (Даркевич 1961, 95; Kucypera-Pranke-Wadyl 2011, 41-51), and also of St. Olaf (Egan 1998, 303). Axes from the end of the medieval period are most likely associated with the cult of St. Wolfgang (924-994; Holzer 1935, 71). The future saint took part in the mission to Hungary, and as the bishop of Regensburg, he became famous for his excellent organizational skills (Zinnhobler 1975, 9). In many depictions of Wolfgang, he was portrayed with an axe in his right hand; in the vast majority of images this axe is miniature (Fig. 5), mentioning only the images of the Bishop of Regensburg from the altars of Bad Aussee (circa 1475 r.), Bad Oberdorf (circa 1480 r.), Ludesch (1488), Klagenfurt (1500-1510), Nauders (circa 1510), Gebertsham (circa 1515; Hüber 1968; Höfler 1987, Cat. 15; 1998, Cat. 42; Apfelthaler 1982, 63-70). In the above-mentioned works of art, axes usually correspond to Głosek's forms IXa and Xa with an oblique beard. The axe as an attribute of this saint was to be a symbolic commemoration of the event in his life, when he withdrew from public life (Schwaiger 1994, 11-13). After choosing a place of isolation in the wilderness, he prayed, and someday threw his axe into the thicket; the place of its fall was considered chosen by God for the construction of the hermitage (Kellner 1998). St. Wolfgang was the patron saint of shepherds, sailors, carpenters and sculptors (Grabowska-Lysenko 2020). It cannot be ruled out that some miniature axes referred to the cult of St. Wolfgang as the protector of these professions.

According to V. P. Darkevič, the association of early medieval axes with the cult of thunderwielding Perun, Perkunas or Thor was supposed to protect the owner against lightning during storms (Даркевич 1961; cf. Koktvedgaard-Zeitzen 1997, 3, 17). From ethnographic analogies we know that axes of standard size fulfilled also various apotropaic functions. According to the Slavic beliefs, the axe was a universal protection against all evil. It was placed under the cradle or bed with the blade facing up; on the threshold with the blade in or out, as well as thrown out over the threshold at the wedding and birth rituals (Bąbel 1980, 17). The axe used also to serve as a protection against a lightning strike; its connection with fertility is also emphasized (ibidem, 18). It seems that these roles could have been played by miniature items, which symbolically fulfilled the task, were likely to carry, and at the same time allowed to save a useful tool or a weapon of normal size. Ethnographic sources for the primitive culture of Serbs mention that a model of an axe made of a dead horse' horseshoe was to serve as a shield against a birthing demon. It was then offered to an infant who would wear it for the rest of its life as a protective amulet (ibidem, 16-17).

Unfortunately, certain apotropaic-magical practices may escape our understanding of the world of that time, and at the same time visualize better the multifunctionality of the objects used then. It is rather hard to consider as accidental the discovery of a Neolithic axe in the latrine filling from the turn of the 13th/14th centuries in Stargard (Szeremeta 2019) or the late Neolithic axe
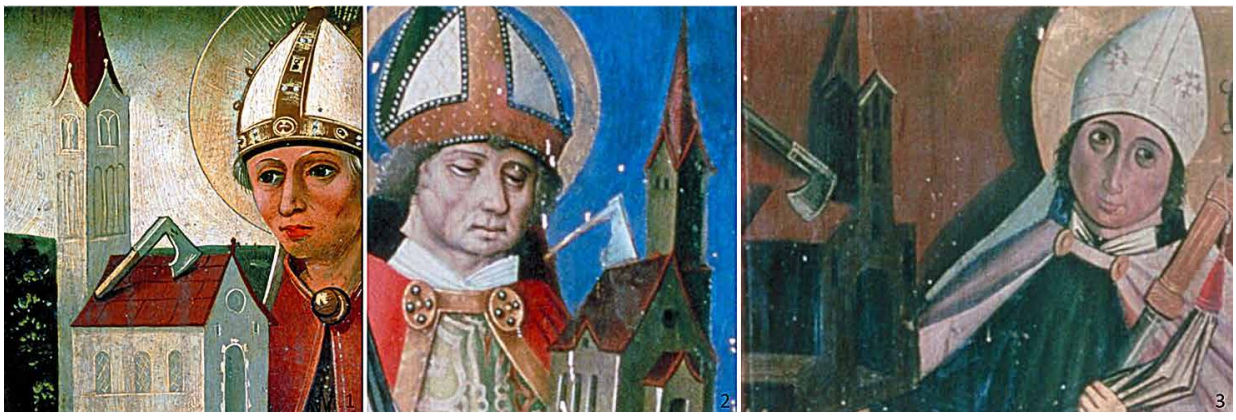

Fig. 5. Depictions of Saint Wolfgang from the altars of Bad Aussee, c. 1475 (1), Klagenfurt with standing saints, $1500-1510$ (2) and Klagenfurt with Vitus Legend, c. 1470-1480 (3). 1 after Hüber 1968; 2 after Höfler 1998; 3 after Höfler 1987.

Obr. 5. Vyobrazení svatého Wolfganga z oltářů v Bad Aussee, asi 1475 (1), Klagenfurt, se stojícími světci, 1500-1510 (2) a Klagenfurt s legendou o sv. Vítovi, asi 1470-1480 (3). 1 podle Hüber 1968; 2 podle Höfler 1998; 3 podle Höfler 1987. 
in the cesspit dated to the beginning of the 14th century in Rostock. Moreover, a stone axe was discovered in the wall surrounding the church cemetery in Ostroróg (Kowalski-Matuszewska 2012, 69). ${ }^{4}$ Can it be assumed, in view of the repetition of certain practices that the people of that time were not aware of the function, raw material or origin (age) of the items they used? (Kurasiński-Skóra 2020, 317, Fig. 17).

The above-mentioned magical procedures related to the production of this type of amulets from a horseshoe, thanks to metallographic analysis, could allow their easy identification. The blacksmith's efforts to transform the original object into a different one would also significantly change the structure of the metal (Hensel 2009, 210, 212). Unfortunately, metallurgical analyses of the axes in question have not been carried out so far. The only exception is a specimen from the stronghold-castle in Międzyrzecz (Głowacki 1959, 2; 1960, 8). Yet, the analysis did not confirm that the axe was made from an originally different object. However, they showed that in the case of these objects, their use as a specialized carpentry tool should also be taken into account, which was suggested earlier by S. Kurnatowski (1961, 138, Fig. 44:5), followed by J. Sztetyłło (1978, 78-79, Fig. 53:e). A similar function for the specimen from Plemięta was also considered by A. Kola $(1985,150$, Pl. XX:3). This may be likewise implied by the asymmetry of the blade, noticeable in the specimens from Brodnica, Horodysko, Skoroszowice, Poznań, Silesia, Solska Forest, Wrocław and Lake Wolskie, which is clearly a feature of carpentry axes. Metallographic analysis of the specimen from Międzyrzecz showed forging the axe from soft iron with a ferritic structure containing slag inclusions, and hardening its blade by using a hard, steel overlay with a heterogeneous pearlitic-ferritic and ferritic-pearlitic structure (Fig. 6). After forging, the axe was not thermally tempered (Głowacki 1959, 2; 1960, 8). Similar technological solutions are known from carpentry specimens of standard sizes (Hošek 2006, 298-300). Tools of this type could have been hidden in carpentry manuals under the term Handbeil, used for hewing small pieces of wood and for precise carpentry processing, including making grooves in beams (Heurich 1877, 54). It
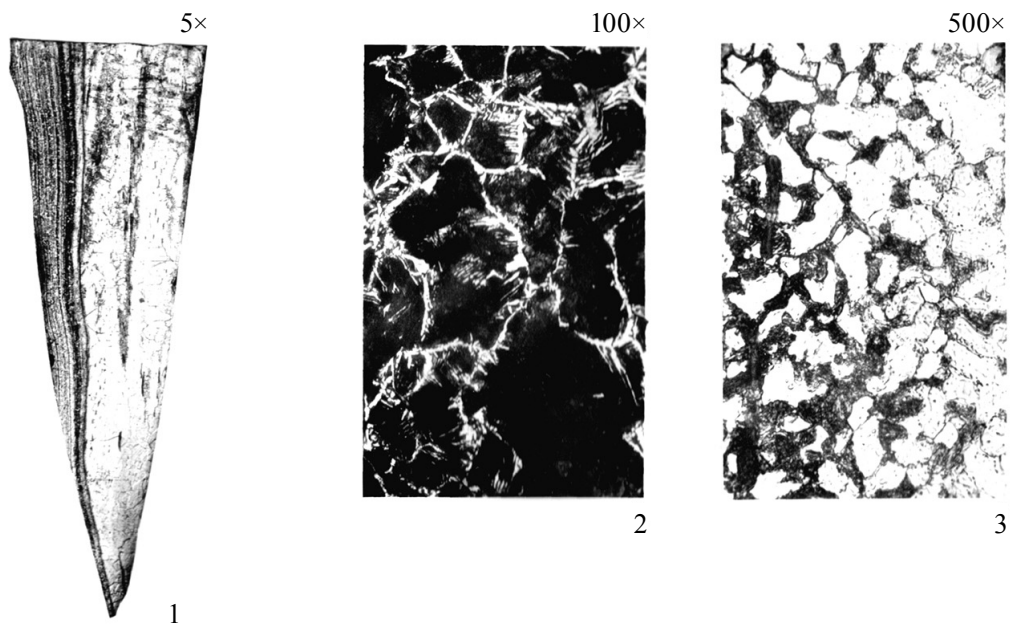

3

Fig. 6. Microstructure images of the axe from Międzyrzecz stronghold obtained during metallographic examination. After Glowacki 1967.

Obr. 6. Snímky mikrostruktury sekerky z tvrze Międzyrzecz získané při metalografickém průzkumu. Podle Glowacki 1967.

4 Other examples of this phenomenon, linked to protection against lightning (the co called Thunderbolts), are known from defensive settlements and households of Bohemia and Slovakia, such as castles Křivoklát, Kozí Hrádek, Týřov, Lelekovice, Čtyřkol and housholds in Panoší Újezd and Marčovice (Vích-Kašpar 2014, 901). 
should be emphasized however that among well-known medieval and early modern depictions of carpenters at work, there are no tools of this type (Goodman 1962, 30-31).

Obviously, the presented observations do not exhaust the possible interpretations of these artefacts. There is no doubt that they could have been used for various purposes. The final determination of the function would have to be based on metallographic analysis and an in-depth analysis of the cultural context of occurrence. However, it seems that smaller specimens, approx. $5 \mathrm{~cm}$ long, could have been used as apotropaic amulets or objects related to the cult of St. Wolfgang. The slightly larger axes, with hardened blades, were most likely used as specialized carpentry tools, perhaps also in self-defense, if necessary. The final determination of the functions of these axes, however, goes beyond the scope of this contribution and requires further studies on a larger number of artefacts.

\section{Acknowledgements}

For their help, support, and contributions in all forms (access to objects, literature, images, the sharing of research, constructive criticism, proofreading) the author is grateful to following persons: Hanna Kočka-Krenz (Archaeology Department of Adam Mickiewicz University in Poznań), Magdalena Szczecińska and Krzysztof Demidziuk (Archaeological Museum, Wrocław), Piotr Kotowicz (Historical Museum, Sanok), Radosław Liwoch (Archeological Museum, Kraków), Anna Sabak-Stachowiak (Archaeological Museum of the Mid-Odra River Area, Zielona Góra), Julianna Sójkowska-Socha (Museum of the Küstrin Fortress, Kostrzyn nad Odrą) and Christopher Onzol (California).

Translated by Arkadiusz Michalak, proofreading by Christopher Onzol

\section{Bibliography}

APFELTHALER, J., 1982: Der Altar von Gebertsham, Oberösterreich Kulturzeitschrift 32, no. 4, 63-70.

BANACH, B., 2016: Zabytki wydzielone z warstw późnośredniowiecznych. In: Międzyrzecz. Gród i zamek w wiekach IX-XIV. Wyniki prac wykopaliskowych z lat 1954-1961 (Kurnatowski, S., ed.), 321-353. Warszawa.

BASTIAN, W., 1959: Zur Kamladenforschung. Die Kamladen von Lassan bei Klocksdorf, kreis Gadebusch und ihre Funde, Jahrbuch für Bodendenkmalpflege in Mecklenburg 1959, 162-188.

BĄBEL, J., 1980: Kult topora w neolicie ziem polskich, Wiadomości Archeologiczne 45, no. 1, 3-44.

BEILKE-VOIGT, I., 1998: Frühgeschichtliche Miniaturobjekte mit Amulettcharakter zwischen Britischen Inseln und Schwarzem Meer. Universitätsforschungen zur prähistorischen Archäologie 51. Schriften zur Archäologie der germanischen und slawischen Frühgeschichte 3 (Hening, J.-Leube, A., edd.). Bonn.

BIEGELEISEN, H., 1927: Matka i dziecko w obrzędach, wierzeniach i zwyczajach ludu polskiego. Lwów.

BLAŽEVIČIUS, P., 2008: Vaikų žaislai ir žaidimai XIII-XVII a. Lietuvoje (remiantis archeologijos duome-nimis), Lietuvos archeologija 33, 71-122.

BOGUSZEWICZ, A., 2000: Problem zamku typu przejściowego na przykładzie warowni w Pieszycach. In: Archaeologia et historica. Księga jubileuszowa dedykowana Pani Profesor Romanie-Barnycz-Głupieńcowej (Kajzer, L. et al., edd.), 65-86. Łódź.

BRACKER, J., 1989: Kinderarmbrust. In: Die Hanse. Lebenswirklichkeit und Mythos 2, Austellungskatalog für Hamburgische Geschichte, 562. Hamburg.

DĄBROWSKA, E., 1965: Studia nad wczesnośredniowiecznym osadnictwem ziemi wiślickiej. Wrocław Warszawa - Kraków.

DELIMATA, M., 2004: Dziecko w Polsce średniowiecznej. Poznań.

EGAN, G., 1997: Children's Pastimes in Past time - Medieval toys found in British Isles (with observations on excavated dice). In: Material Culture in Medieval Europe, Papers of the 'Medieval Europe Brugge 1997’ Conference. Vol. 7 (de Boe, G.-Verhaeghe, F., edd.), 413-421. Zellik. 
GŁOSEK, M., 1996: Późnośredniowieczna broń obuchowa w zbiorach polskich. Warszawa - Łódź.

- 1997: Militaria znalezione w fosie na Placu Dominikańskim we Wrocławiu, Studia Archeologiczne 29, 151-167.

- 2004: Średniowieczne uzbrojenie plebejskie w świetle odkryć archeologicznych, źródeł ikonograficznych i pisanych na ziemiach polskich. Acta Universistatis Lodziensis, Folia Archaeologica 24, $237-248$

GŁOWACKI, Z., 1959: Powierzchniowe badania makroskopowe zabytków metalowych z Międzyrzecza. Poznań. Typescript in the archive of Institute of Archaeology and Ethnology, Polish Academy of Science, Poznań Branch.

- 1960: Badania metaloznawcze zabytków metalowych z Międzyrzecza. Poznań. Typescript in the archive of Institute of Archaeology and Ethnology, Polish Academy of Science, Poznań Branch.

GOODMAN, W. L., 1962: The History of Woodworking Tools. London.

GRABOWSKA-LYSENKO, A., 2020: Materialne świadectwa kultu św. Wolfganga u schyłku średniowiecza w Prusach jako element religijnego dziedzictwa regionu. In: Stare i nowe dziedzictwo Torunia, Bydgoszczy i regionu II. Studia i materiały z dziedzictwa kulturowego Torunia i regionu. Vol. 3 (Raczkowski, J.Jakubek-Raczkowska, M., edd.), 75-89. Toruń

GRĄŻAWSKI, K., 2003: Odkrycia na zamku krzyżackim w Brodnicy w świetle badań 1992-1997. In: Pogranicze polsko-krzyżackie i pruskie materiały z konferencji naukowej, Górzno, 1-2 czerwca 2002 r. Vol. 1 (Grążawski, K., ed.), 351-371. Włocławek-Brodnica.

HENSEL, Z., 2009: Omówienie wyników badań „miecza” ze Świebodzina, Acta Militaria Mediaevalia 5, $210-212$.

HEURICH, J., 1877: Przewodnik dla cieśli, obejmujący cały zakres ciesielstwa. 3rd edition. Warszawa.

HOFFMANN, V., 1996: Allerlay kurtzweil. Mittelalterliche und frühzeitliche Spielzeugfunde aus Sachsen, Arbeits- und Forschungsberichte zur Sächsische Bodenkampflege 38, 127-200.

HOLZER, F. W., 1935: St. Wolfgang, ,ein Heiliger der Spätgotik“, Jahresbericht des Vereins zur Erforschung der Regensburger Diözesangeschichte 10, 71.

HOŠEK, J., 2006: Metalografie železných předmětů ze semonické tvrze ve světle studovaných výkovů ze středověkých tvrzí, vesnic a měst, PA XCVII, 265-320.

HÖFLER, J., 1987: Die Tafelmalerei der Gotik in Kärnten (1420-1500). Klagenfurt.

- 1998: Die Tafelmalerei der Dürerzeit in Kärnten (1500-1530). Klagenfurt.

HÜBER, F., 1968: Spitalskirche Bad Aussee. S. 1.

IRÁSNÉ MELIS, K., 2004: Régészeti kutatások a Budapesti középkori csőt faluban II, Communicationes Archaeologicae Hungariae 2004, 173-222.

JASIŃSKI, M., 1982: Archeologiczne badania podwodne w jeziorze Wolskim. Typescript of Masters Thesis in the archive of Archaeology Department, Adam Mickiewicz University in Poznań.

KAUTE, P.-RÜTZ, T.-ZORN, J., 2018: Rostock, Hansestadt, Flurbezirk I, Innenstadt. Fpl. 523, Bodendenkmalpflege in Mecklenburg-Vorpomern 65 (2017), 372-379.

KELLNER, M. G., 1998: Wolfgang, Bischof von Regensburg. In: Biographisch-Bibliographisches Kirchenlexikon 13, 1528-1529. Herzberg.

KĘDZIERSKI, A.-WYCZÓŁKOWSKI, D., 2014: Toporki miniaturowe z badań na Starym Mieście w Kaliszu, Wielkopolskie Sprawozdania Archeologiczne 15, 99-106.

KOKOWSKI, A., 1997: Metalowe wisiorki w kształcie topora na terenie Barbaricum na północ i północny-wschód od limesu rzymskiego, w okresie rzymskim i we wczesnym okresie wędrówek ludów. In: 20 lat archeologii w Masłomęczu. Vol. 1. Weterani (Ilkjær, J.-Kokowski, A., edd.), 99-116. Lublin.

KOKTVEDGAARD-ZEITZEN, M. K., 1997: Amulets and Amulet Use in Viking Age Denmark, Acta Archaeologica 68, 1-74.

KOLA, A., 1985: Narzędzia do obróbki drewna z grodziska w Plemiętach. In: Plemięta. Średniowieczny gródek w ziemi chełmińskiej (Nadolski, A., ed.), 149-157. Warszawa - Poznań - Toruń.

- 2003: Późnośredniowieczne grodzisko w Skłudzewie w ziemi chełmińskiej, Archaeologia Historica Polona 13, 277-285. 
KOLA, A.-WILKE, G., 1975: Wstępne wyniki ratowniczych prac wykopaliskowych przeprowadzonych na grodzisku późnośredniowiecznym w Słoszewach, pow. Brodnica w 1973 r., Acta Universitatis Nicolai Copernici. Archeologia 5, 107-118.

KOŁODZIEJSKI, A., 1965: Rozwój archeologii na terenie województwa zielonogórskiego w dwudziestoleciu Polski Ludowej. Zielona Góra.

- 1967: Trzciel, pow. Międzyrzecz w świetle wykopalisk. Zielona Góra.

KOTOWICZ, P. N., 2004: Wojowie i rycerze. Uzbrojenie średniowieczne na pograniczu polsko-rusko-słowackim. Katalog wystawy, Sanok 2004: Muzeum Historyczne w Sanoku.

- 2008: Zabawka czy oręż ćwiczebny? Przyczynek do badań nad problematyką drewnianych naśladownictw średniowiecznych mieczy. In: Nie tylko broń. Niemilitarne wyposażenie wojowników w starożytności i średniowieczu, Acta Archaeologica Lodziensia 54 (Świętosławski, W., ed.), 89-98. Łódź.

- 2012: Na tropie spektakularnej omyłki. Nowe spojrzenie na toporek z „napisem“ z Ostrowa Tumskiego w Poznaniu, Acta Universitatis Lodziensis. Folia Archaeologica 29, 111-122.

KOTOWICZ, P. N.-MUZYCZUK, A., 2008: Militaria średniowieczne z Królewskiego Miasta Krosna, Acta Militaria Mediaevalia IV, 125-166.

KOWALSKI, K.-MATUSZEWSKA, A., 2012: Wprowadzenie do problematyki kulturowej zabytków neolitycznych. In: Zaginione - ocalone. Szczecińska kolekcja starożytności pomorskich (Kowalski, K.Kozłowska-Skoczka, D., edd.), 69-79. Szczecin.

KUCYPERA, P.-PRANKE, P.-WADYL, S., 2010: Wczesnośredniowieczne miniaturowe toporki metalowe z Europy Środkowo-Wschodniej i Północnej. Korpus zabytków. In: Życie codzienne przez pryzmat rzeczy (Kucypera P.-Wadyl, S., edd.), 103-176. Toruń.

- 2011: Wczesnośredniowieczne toporki miniaturowe. Toruń.

KUNICKA-OKULICZOWA, Ł., 1959: Wczesnośredniowieczne zabawki i gry z Gdańska. In: Gdańsk wczesnośredniowieczny 1 (Kamińska, J., ed.), 107-143. Gdańsk.

KURASIŃSKI, T., 2009: Militaria jako element wyposażenia wczesnośredniowiecznych pochówków dziecięcych - próba interpretacji na przykładzie znalezisk z ziem polskich, Archeologia Polski 54, no. 2, 209-248.

KURASIŃSKI, T.-SKÓRA, K., 2020: From the past into the future - archaica as a research problem (on the basis of medieval and modern period finds from Central-Eastern Europe. In: Slivers of the Antiquity. The Use of Ancient Coins in Central, Eastern and Northern Europe in the Medieval and Modern Periods Okruchy starożytności. Użytkowanie monet antycznych w Europie Środkowej, Wschodniej i Północnej w średniowieczu i w okresie nowożytnym (Bogucki, M.-Dymowski, A.-Śnieżko, G., edd.), 301-366. Warszawa.

KURNATOWSKI, S., 1961: Rozwój Międzyrzecza w świetle badań archeologicznych z lat 1954-1958. In: Kurnatowski, S.-Nalepa, J., Z przeszłości Międzyrzecza, 61-181. Poznań.

ŁASZKIEWICZ, T.-MICHALAK, A., 2007: Broń i oporządzenie jeździeckie z badań i nadzorów archeologicznych na terenie Międzyrzecza, Acta Militaria Mediaevalia 3, 99-176.

ŁAWRYNOWICZ, O.-STRZYŻ, P., 2003: Nowe zabytki broni obuchowej z okolic Roztocza, Archeologia Polski Środkowowschodniej 6, 258-264.

ŁUKASIEWICZ, K., 1938: Przedmioty żelazne z Gniezna. In: Gniezno w zaraniu dziejów (od VIII-XIII w.) w świetle wykopalisk (Kostrzewski, J. ed.), 41-56. Poznań.

MICHALAK, A., 2015: Broń w wodnej toni. Uwagi o akwatycznych znaleziskach broni późnośredniowiecznej, na marginesie odkryć z Lutola Mokrego. In: Woda - żywioł ujarzmiony i nieujarzmiony. Materiały z konferencji w Janowcu w 2012 r. Biblioteka Archeologii Środkowego Nadodrza 8 (Jaszewska, A.-Michalak, A., edd.), 289-314. Zielona Góra.

- 2019: Arma Confinii. Przemiany późnośredniowiecznej broni na rubieżach Śląska, Wielkopolski, Brandenburgii i Łużyc. Zielona Góra.

MÖBES, G.-TIMPEL, W., 1987: Die Burg Lodenschitz in der Gemarkung Schlöben bei Stadtroda, Alt-Thüringen 22/23, 297-367.

NADOLSKI, A., 1954: Studia nad uzbrojeniem polskim w X, XI i XII wieku. Łódź.

PANER, H., 2016: Gdańsk na pielgrzymkowych szlakach średniowiecznej Europy. Gdańsk. 
POPOVICI, R., 2002: Negoeşti, un sat din zona neamţ în secolele XIV-XVII, Arheologia Medievalâ IV, 27-45.

RØNNE, O., 2008: Langhus, økser, gårder og grenser under senneolitikum. In: Facets of Archeology: Essays in Honour of Lotte Hedeager on her 60th Birthday (Childis, K.-Lund, J. -Prescott, Ch., edd.), 577-584. Oslo.

SAWICKI, J., 2014: Średniowieczne świeckie odznaki w Polsce na tle Europejskim. Wratislavia Antiqua 20. Wrocław.

SCHWAIGER, G., 1994: Bischof Wolfgang von Regensburg (ca. 924-994): Geschichte, Legende und Verehrung. In: Wallfahrten im Bistum Regensburg: zur Tausendjahrfeier des Todes des hl. Bischofs Wolfgang (Schwaiger, G.-Mai, P., edd.), 11-13. Regensburg.

SENSFELDER, J., 2008: Pferdchen, Trommel und Armbrust - Kleinschnepper als Kinderspielzeug, Waffen und Kostümkunde 50, no. 2, 1-18.

SIKORSKI, CZ., 2000: Broń średniowieczna z jeziora Wolskiego w gm. Rogowo woj. bydgoskie, Rocznik Kasprowiczowski 9, 97-114.

SPENCER, B., 1998: Pilgrim Souvenirs and Secular Badges. Medieval finds from excavations in London 7. London.

STARÝ, J.-KOZÁK, J., 2010: Hranice světů: Staroseverský Midgard a Útgard ve strukturalistických a poststrukturalistických interpretacích, Religio 18, no. 1, 31-58.

STEUER, H., 1993: Werkzeug der Schiffbauer vom Rheinufer in Köln. In: Archäologie des Mittelalters und Bauforschung im Hanseraum: Eine Festschrift für Günter P. Fehring (Gläser, M., ed.), 311-330. Rostock.

SZCZUREK, T., 2005: Skarb monet z XV wieku odkryty w roku 200 w Międzyrzeczu. In: Ziemia Międzyrzecka. Śladami historii. Materiały z III sesji historycznej zorganizowanej w Muzeum w Międzyrzeczu, 13 maja 2005 r. (Mykietów, B.-Tureczek, M., edd.), 127-146. Międzyrzecz - Zielona Góra.

SZEREMETA, M., 2019: Siekiera kamienna. In: Archeologia Stargardu V.1 (Majewski, M., ed.), 49-52. Poznań - Stargard.

SZTETYŁŁO, J., 1978: Rzemiosła metalowe wraz z uzbrojeniem. In: Historia kultury materialnej Polski w zarysie (Hensel, W.-Pazdur, J., edd.). Vol. 2: Od XII do XV wieku (Rutkowska-Płachcińska A., ed.), 73-108. Wrocław - Warszawa - Kraków - Gdańsk.

ŚWIĄTKIEWICZ, P., 2010: Militaria ze średniowiecznego grodziska w Raciążu, Acta Militaria Mediaevalia $6,7-92$.

ŚWIDERSKA, U., 2001: Kultura rycerska w średniowiecznej Polsce. Zielona Góra

S̆MITEK, Z., 2007: Kaj raste brez korenja? O kamnih s posebnimi svojstvi na Slovenskem, Studia mythologica Slavica 10, 179-195. https://doi.org/10.3986/sms.v10i0.1710

TEREI, G.-HORVÁTH, A., 2007: Az Árpád-kori Kána falsu vasleletei I, Communicationes Archaeologicae Hungariae 2007, 235-246.

TRZECIECKI, M.-AUCH, M.-STAŃCZUK, K., 2020: Grodzisko Piotrówka w Radomiu w świetle badań archeologicznych 2010-2013. Część I: stratygrafia i chronologia. Warszawa.

VÍCH, D.-KAŠPAR, P., 2014: Nález hromového klínu v Panoším Újezdu na Rakovnicku, ASČ 18, 901-902.

VLASATÝ, T., 2020: Possible function of the "Perun Axes". Available on-line at: https://sagy.vikingove.cz/ possible-function-of-the-perun-axes/, access 21. 6. 2021.

WILLEMSEN, A., 1997: Medieval Children's Toys in the Netherlands. Production, Sale, and Trade. In: Material Culture in Medieval Europe, Papers of the 'Medieval Europe Brugge 1997' Conference. Vol. 7 (de Boe, G.-Verhaeghe F., edd.), 405-412. Zellik.

ZINNHOBLER, R., 1975: Der Heilige Wolfgang: Leben, Legende, Kult. Linz.

ŻOŁĄDŹ-STRZELCZYK, D., 2013: „A cacek też dużo było”. Zabawki dziecięce na ziemiach polskich w średniowieczu i epoce nowożytnej, Kwartalnik Historyczny CXX, no. 1, 5-30.

ДАРКЕВИЧ, В. Л., 1961: Топор как символ Перуна в древнерусском язычестве, Советская археология 4, 91-102.

МАКАРОВ, Н. А., 1992: Древнерусские амулеты-топорики, Российская археология 2, 41-56.

САВИЦЬКИЙ, В.-ОХРІМЕНКО, Г., 2007: Мі́ні́атюрні́ сокирки-амулети джерело для реконстукцї дохристиянських вирувань давніх словян, Старий Луцк III, 130-138. 


\section{Př́́prava na život nebo ochrana před smrtí? Poznámky k pozdně středověkým miniaturním sekerkám na př́íkladech z pomezí Velkopolska, Slezska a Braniborska}

Při sběru materiálů pro práci věnovanou pozdně středověkým zbraním a zbroji z pohraničí Slezska, Velkopolska, Braniborska a Lužice (na západní hranici Polska, v dnešním Lubušském vojvodství) se podařilo nalézt třri miniaturní sekerky (s délkou nepřesahující $10 \mathrm{~cm}$ ), které podobou připomínají běžné pozdně středověké exempláře. První artefakt byl získán při archeologickém výzkumu tvrze Międzyrzecz (obr. 2:1), ve vrstvách datovaných do let 1269 až 1280/1290. Druhý exemplář z Międzyrzecze (obr. 2:2) byl objeven v rámci výzkumu městské parcely, kde se vyskytovaly především vrstvy charakteristické pro 15 . století a novověk. Třetí, o něco větší miniaturní exemplář byl získán při archeologickém výzkumu tvrze typu motte v Trzcielu. Tvarově odpovídá sekerám typu IX podle M. Głoska (obr. 2:3). Stratigrafie lokality umožňuje datovat tuto sekeru pouze rámcově do období existence tvrze, tedy mezi 13. a 16. století.

Z území Polska je známo přes 20 podobných pozdně středověkých seker s výrazně zmenšenými rozměry (obr. 1). Drtivá většina těchto seker pochází z fortifikovaných lokalit či městských archeologických kontextů, které však neposkytují jednoznačné podklady pro určení jejich funkce (obr. 3-4). Některé z těchto exemplářů jsou datovány pouze relativně a rámcově, a to do období od 13. do 15. století. V literatuře byl tento typ artefaktů považován jak za amulety, tak za hračky, zbraně, odznaky či nástroje. Nelze vyloučit jejich souvislost s dětskou sférou, zdá se však, že menší exempláře o délce cca $5 \mathrm{~cm}$ mohly sloužit rovněž jako apotropaické amulety nebo předměty související s kultem svatého Wolfganga (obr. 5). O něco větší sekerky s kaleným ostřím byly s největší pravděpodobností použivány jako specializované tesařské nástroje (obr. 6), $\mathrm{v}$ prŕípadě potřeby snad i jako př́ležitostné zbraně.

Arkadiusz Michalak PhD, The Archaeological Museum of the Mid-Odra River Area, Długa Street 27, 66-008 Świdnica, Poland, a.michalak@muzeum-swidnica.org 
